\title{
Historia socioeconómica y ficción literaria: consecuencias de la Gran Depresión en Of Mice and Men (1937) de John Steinbeck
}

\section{Socio-Economic History and Literary Fiction: The Consequences of the Great Depression on Of Mice and Men (1937) by John Steinbeck}

\section{Resumen}

La mayor parte de los temas generales de la historia económica, por su naturaleza social, admiten su abordaje desde numerosas perspectivas, como las que muestran los postulados del sociólogo germano Max Weber. Siguiendo los criterios que se desprenden de la concepción socioeconómica weberiana, advertimos que las causas y consecuencias de la Gran Depresión de los años 30 en EE.UU. puede considerarse uno de los hechos más frecuentemente estudiados con bibliografía proveniente tanto de la ficción literariacomo de otras esferas del arte. El multipremiado John Steinbeck, autor de varios relatos que registran el mayor fracaso económico-financiero de la historia moderna, nos propone una mirada alternativa en Of Mice and Men (1937). Esta criticada y controvertida novela es un documento de protesta y denuncia social, reflejado en las andanzas de George Milton y Lennie Small, dos peones rurales migrantes que representan a los miles de jornaleros que emprendieron un éxodo hacia el Oeste estadounidense,enfrentando los efectos devastadores de la mayor crisis económica mundial que conoce el sector agrícola del mundo desarrollado.

Palabras clave: Gran Depresión; jornaleros migrantes; novela; De ratones y hombres; John Steinbeck.

\footnotetext{
${ }^{1}$ Licenciada en Letras. Facultad de Humanidades, Universidad Nacional del Nordeste (Unne). Correo electrónico: angelinacazorla@hotmail.com
} 


\section{Abstract}

Most of the general topics of Economic History, due to their social nature, admit an approach from various perspectives, according to the German sociologist Max Weber. Following his criteria which emerge from the socio-economic Weberian conception, wehave noticed that the causes and consequences of the 1930s Great Depression in the USA is, perhaps, one of the most frequently considered topics by bibliography coming from literary fiction and other spheres of art. The multi-awarded John Steinbeck, author of several stories which record the greatest economic-financial failure in modern history, proposes an alternative view in Of Mice and Men (1937). This criticized and controversial novel is a document of protest and social denunciation, through the adventures of George Milton and Lennie Small, two rural migrant laborers who represent the thousands of day laborers in exodus towards the American West facing the devastating effects of the greatest economic crisis in the agricultural sector of the developed world.

Keywords: Great Depression, migrant workers, novel, Of Mice and Men, John Steinbeck.

\section{Introducción}

La literatura es, quizás, uno de los recursos didácticos más utilizados por los docentes en la enseñanza crítica y reflexiva de la historia política, social y económica de los pueblos, ya que el impacto de la imaginería y de la ficción narrativa pueden ser aún más seductores y poderosos que las clases magistrales. De los tópicos de la historia socioeconómica, la Gran Depresión de los años treinta en los EE.UU. ha sido, probablemente, uno de los más frecuentemente enseñados desde lo ficcional. Los textos y autores que se ocupan de este tema son muy profusos, aunque insuficientemente conocidos por el público lector en general. The Grapes of Wrath (1939) es, indudablemente, el texto de mayor difusión sobre la Gran Depresión. Esta obra maestra de John Steinbeck (galardonada con el premio Pulitzer al año siguiente de su edición) aborda el impacto de la mayor crisis económica de la historia contemporánea y refleja, con precisión, sus devastadores efectos sociales. A ella le seguirá East of Eden (1952). Este autor, oriundo de Salinas, un hermoso valle agrícolaen el norte central de 
California ${ }^{2}$, merecedor, además, del premio Nobel en 1962, inmortalizóen tres de sus trabajos elfracaso financiero que dejó a naciones enteras sumergidas en la desesperación, la pobreza y la desconfianza en el sistema mundial. Como consecuencia de un ejercicio de escritura experimental surge, lo que el mismo autor explicó en un ensayo, una play-novelette (Steinbeck, 2002c: 177-180): tres trabajos con forma de novela breve pero escritos para ser representados por una compañía teatral. Nos ocuparemos aquí de Of Mice and Men (1937), el primero y el más exitoso resultado de su innovación escritural:un relato durísimo, descarnado y directo que narra las peripecias de George Milton y Lennie Small, dos peones rurales migrantes, buscando trabajo de rancho en rancho y enfrentando las consecuencias de la recesión.

\section{El camino a la Gran Depresión de $\mathbf{1 9 3 0}$}

El primer decenio del siglo XX comienza con la huella de la tragedia: en 1901 el presidente norteamericano William McKinley es asesinado en Nueva York (Remini, 2008) y en 1906 un terremoto destruye la ciudad de San Francisco (California) causando más de mil muertos. A estas tragedias le seguirán desórdenes sociales, huelgas, revueltas, reivindicaciones continuas (reprimidos brutalmente por la policía) y la Gran Guerra. Eran pésimos augurios y terribles presagios para una centuria predestinada a la violencia, el sufrimiento y la matanza. Era tal la imagen dominante de estos primeros años que el historiador británico Eric Hobsbawm titula a la Primera Parte de su mirada panorámica del siglo XX: La Era de las Catástrofes, no solo porque ha sido el siglo más mortífero de la historia a causa de la envergadura, la frecuencia y la duración de los conflictos bélicos que han asolado sin interrupción (excepto durante un breve período en los años veinte), sino también por las catástrofes humanas sin parangón posible que han causado desde las mayores hambrunas hasta el genocidio sistemático. Para Hobsbawm, el siglo XX se inicia, cronológicamente, con la guerra total, la revolución mundial y el abismo económico (Hobsbawm, 1999).

La Primera Guerra Mundial había convertido a EE.UU. en el principal proveedor -y acreedor- de materias primas y productos alimenticios básicos de Europa: trigo, algodón,

\footnotetext{
2Escenario de la mayoría de sus ficciones (Shilliglaw, 2006: 38).
} 
azúcar, caucho, seda, cobre, estaño y café (Hobsbawm, 1999). Esta bonanza económica del decenio de 1920 (1924-1929), a su vez, permitió un meteórico crecimiento industrial que dio inicio aun fugaz -aunque intenso- período pertinentemente denominado The Roaring Twenties (Remini, 2008: 220). Ya a partir de 1918, la prosperidad era notoria y evidente. Norteamérica había salido robustecida de la contienda: había ganado en el ámbito de la economía, pues se apoderó de los mercados tradicionalmente ocupados por los europeos yen política,puesto que se convirtió en la gran superpotencia mundial. Sus empresas se modernizaron y mecanizaron,convirtiendo al país en el más competitivo del mundo. La clave de la industrialización norteamericana fue su comercio interior, ampliado por oleadas de inmigrantes europeos (Remini, 2008) ${ }^{3}$; un mercado sin barreras ni cortapisas aduaneras, con altos aranceles proteccionistas y muy bajos impuestos.

Durante estos felices años veinte, los movimientos obreros entraron en un período de descanso porque, a pesar de la gran diferencia entre las clases sociales, había suficiente pan y trabajo para todos. El desarrollo económico, la incorporación de grandes masas de campesinos a la vida urbana, el descenso del analfabetismo, el acceso de la mujer a la vida social y la nueva legislación laboral regían las relaciones entre obreros y patrones. La Gran Guerra había arruinado a unos y favorecido a otros. Norteamérica había resultado indemne debido a la lejanía del teatro bélico y el ritmo de producción impuesto por la guerra desarrolló su industria de tal modoque, fácilmente, logró la hegemonía.

Los norteamericanos no necesitaban ni dependían del resto del mundo, pues desde la finalización de la Primera Guerra requerían importar menos capital (excepto algunas pocas materias primas) y, en cuanto a sus exportaciones, Hollywood-la meca de la gran pantallamonopolizaba, prácticamente, el mercado internacional del cine sonoro:

Percatados de su papel de país rector, los Estados Unidos se dedicaron a exportar imagen. Para ello contaron con otra industria en ascenso en la que la hegemonía americana llegaría a ser absoluta, el cinematógrafo. El cine se convirtió en el mayor espectáculo y los ídolos de América

\footnotetext{
${ }^{3}$ Oleada inmigratoria que, posteriormente, se limitó con la First Inmigration Quota Act de 1921, debido a la masiva llegada de mexicanos (Remini, 2008).
} 
-Douglas Fairbanks, Rodolfo Valentino, Charlie Chaplin, Grata Garbo, Mae Murray o Mary Pickford - llegaría a ser ídolos del mundo entero. (Ortiz, 2008: 17)

Los años veinte fueron, asimismo, los años de la construcción inmobiliaria, del crecimiento de las obras públicas y el auge de todas las fábricas para el consumo. Eran los tiempos de la producción masiva y los nuevos inventos:radiorreceptores, discos de gramófono, refrigeradores, aspiradoras, estufas, lavadoras, cocinas eléctricas, teléfonos, máquinas de escribir, automóviles, terrenosy casas, entre otros.En la América de Calvin Coolidge, presidente cuyo mandato cubre estos años, la cultura lúdica (Fraser, 2016) se potenció con la apertura de cabarets, music halls, espectáculos de jazz y otros centros de diversiones que fomentaban los concursos de belleza y las maratones de bailes.Las costumbres se relajaron, pues el nuevo estilo femeninoimpuesto por Greta Garbo, con el cual la mujer expresaba una nueva conciencia independiente y liberada, apuntaba a las faldas más cortas que revelaban las piernas, los vestidos con volados y gasas y la línea del talle a la altura de las caderas (Ortiz, 2008).

Por otro lado, la agricultura, que también se había beneficiado altamente por la actividad bélica durante las dos primeras décadas, no logró alcanzar el mismo crecimiento meteórico de los otros sectores, pues los precios agrícolas se mantuvieron muy por debajo de los valores industriales, generando un desequilibrio desfavorable para el sector primario. Al finalizar la guerra, se produjo un desajuste entre la oferta generada por Estados Unidos y la escasez de demanda procedente de Europa, lo que provocó la baja en el valor y el hundimiento de precios de los productos estadounidenses.Con el ritmo impuesto a la producción, se abarrotaron los mercados, la oferta superó a la demanda europea y cayeron los precios en picada.Esta situación llevó a la ruina de los agricultores que dependían del mercado de exportación. Volver a refugiarse en la tradicional producción de subsistencia no era posible para un país con la envergadura y riqueza económica de EE.UU. Esta circunstancia particular del sector agrícola tuvo como agravante la combinación de otros factores, entre ellos, el económico-financiero. El desempleo alcanzó cifras astronómicas, los salarios se estancaron y, con ello, el poder adquisitivo y la inversión. Los sistemas públicos de seguridad social (subsidio por desempleo 
generalizado, seguro obligatorio contra la enfermedad o los accidentes, medidas contra la vejez sin ingresos, entre otras medidas profilácticas adoptadas, posteriormente, como consecuencia de la Gran Depresión) todavía no estaban en vigencia en EE.UU.(Lamata, 1998) ${ }^{4}$. Tal vez, esta sea la razón por la cual la seguridad social de la clase trabajadora ha sido una preocupación recurrente y extensamente tratada en las novelas de John Steinbeck. Baste solo un ejemplo al recordar que entre los (pocos) peones temporales empleados en la granja donde transcurre Of Mice and Men se encuentran tres individuos minusválidos y legalmente desprotegidos: Candy, un anciano manco; Crooks, un negro lisiado y Lennie, un débil mental.

Sin embargo, la prosperidad, que era un tanto ficticia, dio paso a la euforia especulativa. En 1929 parecía haber más lujo y consumo que nunca. Los Estados Unidos estaban sumidos en una oleadade individualismo, capitalismo yliberalismo,ymuy seguros de las premisasadministrativasdel presidente electo: Herbert Hoover, un republicano de derecha. Había pocos controles y todo lo que servía para hacer dinero (manipulación de las cotizaciones, negocios ilegales, ventas de acciones falsas, etc.) estaba permitido. Con el dinero, que corría con fluidez, se podía gastar, comprar, derrochar y almacenar bienes de consumo duraderos. Con este alto grado de confianza en el futuro, el boom de los (no tan) felices años veinte había producido una gran especulación en torno a la cotización de las acciones de las empresas en los mercados de capitales.Todo el mundo compraba a crédito, incluso las acciones. Wall Street, el centro de finanzas neoyorkino, permitía a los imprudentes comerciantes o los ilusos lustrabotas conseguir valores a crédito y comprar a plazo a través de agentes de bolsas oportunistas que atizaban la fiebre de compra con una inversión inicial mínima. Entre 1928 y 1929, muchos valores bursátiles alcanzaron su cotización más elevada. Por dar un ejemplo, el índice Dow Jones llegó a su punto culminante con una subida de 340 por 100 (Ortiz, 2008). Esta orgía crediticiallegóbruscamente a su fin el 24 de octubre de $1929^{5}$,

\footnotetext{
${ }^{4}$ Estados Unidos fue el último de los países industriales del hemisferio occidental en implementar cualquier clase de seguridad/beneficio social. La de Ley de Seguridad Social se aprobó en 1935, pero no se aplicaba a los trabajadores de color ni a aquellos que realizaban tareas domésticas: mucamas, lavaplatos, porteros, etc. (Lamata, 1998: 46).

${ }^{5}$ Fecha que pasó a la historia como el jueves negro e inició la triste etapa de la Gran Depresión (Blumenthal, 2013 : 95).
} 
cuando el mercado de valores de Wall Streettuvo una súbita caída (de varios puntos), debido a que el valor de las acciones había dejado de reflejar la marcha de la economía real. La Gran Depresión fue una profunda recesión económica que se inició con este derrumbe bursátil en Nueva York y repercutió directamente sobre el sistema bancario, industrial, agrario, comercial y mercantil internacional ${ }^{6}$. La recesión llevó a la caída de los precios, los mercados y las expectativas. Frente a una menor demanda, las áreas dependientes del sector primario fueron las más afectadas. Así, los hacendados, que habían adquirido tierras, animales y maquinarias agrícolas para cumplir con las ventas, quedaron sumergidos en préstamos impagables e hipotecas ejecutables. Incapaces de satisfacer a los acreedores, los propietarios se vieron obligados a malvender sus granjas, abandonar a sus familias, recoger sus pocas pertenencias y buscar trabajo temporario en alguna ilusoria tierra prometida. Este crack borró de un plumazo la supuesta invulnerabilidad de los EE.UU. liberales, capitalistas y republicanos de los prósperos años 20. Nadie podía imaginar, en aquellos primeros momentos, que este desastre financiero impactaría sobre el sistema económicomundial y que se prolongaría por un decenio. La crisis anterior, la que siguió el fin de la Primera Guerra Mundial, había sido intensa, pero no muy larga, y se creía que esta sería también breve y mucho más moderada.

El alto nivel de integración en la economía internacional y el rol protagónico que en ella desempeñaban los EE.UU. hicieron que la crisis se propagara a países centrales y periféricos. La quiebra generalizada del sistema bancario estadounidense arrastró a la banca europea provocando el colapso del sistema monetario internacional.Incluso Argentina, cuyo nivel de actividad económica era muy dependiente dela entrada de divisas y estaba subordinada al capital extranjero, se vio también afectada en no pequeña medida y tardó en salir del déficit comercial.EE.UU. transfirió los efectos de la crisis a los países que se encontraban bajo su influencia, disminuyendo los precios internacionales de las materias primas, repatriando inversiones, restringiendo las importaciones y colocando trabas a las exportaciones. La gravedad de la situación implicaba la inmediata intervención del Estado para la resolución de la crisis, quien adoptó medidas legales de proteccionismo para restablecer la prosperidad de

\footnotetext{
${ }^{6}$ Tan solo la Unión Soviética cerrada comercialmente a Occidente se salvó de la crisis.
} 
la añorada década anterior. En EE.UU. se registró un marcado giro hacia la izquierda bajo su nuevo presidente Franklin D. Roosevelt, quien puso en práctica un programa de recuperación más radical y progresivo: el New Deal.

\section{De ratones y hombres}

Esta brevísima novela, ambientada al oeste de los EE.UU. durante la gran crisis agropecuaria del medio-oeste estadounidense, está basada en las propias experiencias personales del autor, como bracero y recolector de frutas, y en una investigación periodísticaque realizó para el San Francisco News sobre los jornaleros inmigrantes californianos, a quienes llamó"los vagabundos de la cosecha" en sus artículos reunidos en The Harvest Gypsies (Steinbeck, 2002b).

El aumento de la actividad agrícola, para satisfacer la demanda de las potencias en guerra, había causado la erosión del suelo de los estados de las Grandes Praderas. A este deterioro de la tierra, se agregaron la prolongada sequía(1930-1938), las nubes de polvo y arena y los vientos huracanados que azotaron el campo durante largos años convirtiendo a las otrora fértiles praderas en el Dust Bowl (Reis, 2008).En estos cuencos de polvo nada crecía, los animales morían y las cosechas se echaban a perder. Los agricultores, que dependían directamente de la tierra para sobrevivir, quedaron en la ruina y el desamparo. Muchos propietarios de pequeñas granjas fueron a la bancarrota y los arrendatarios no podían pagar el alquiler. Hubo poca ayuda inmediata que el gobierno pudiera ofrecerles. Así, empezó una inmigración en masa hacia la rica y fértil campiña californiana.

Como consecuencia de estos cambios económicos y ecológicos, los trabajadores agrícolas de las Grandes Planicies (Oklahoma, Texas, Kansas, Colorado, Nuevo México y Arkansas) se movilizaron hacia los estados del Pacífico. Esta migración interna de granjeros, el desplazamiento de colonos, la mendicidad, los trabajos intermitentes y la improvisación de campamentos eran una postal cotidiana del período de entre guerras. California, por su clima templado y su suelo favorable, parecía la más adecuada para una gran variedad de cultivos (hortícolas y frutales), y sus granjas eran mucho más modernas y mecanizadas que las que los 
malditos okies ${ }^{7}$ habían dejado en el Este del Edén (Steinbeck, 2002b: 229). En efecto, para 1930 la automatización en los ranchos, las granjas y las huertas había reducido la demanda de recolectores manuales. Así, la realidad de California en la época de la publicación de la novela (1937) suponía que estos trabajadores itinerantes, como George y Lennie, eran (casi) una especie en extinción (Bloom, 2006).

John Steinbeck describe esta masiva migración interna como si fuera un éxodo bíblico: miles de trabajadores rurales desempleados dejaban sus tierras para ir al Oeste a esclavizarse temporalmente en las granjas ajenas, donde abundaban los cereales. Los viajeros intentaban ir en los techos de los trenes o camiones, sin pagar, por la carretera 66, ruta principal del flujo migratorio (Steinbeck, 2002a) hasta la "Tierra Prometida". Este no es el caso de los protagonistas, pues ambos poseían: "tarjetas de trabajo y billetes de autobús" (Steinbeck, 2017: 5$)^{8}$. Los peones afroamericanos sureños, que también migraban al Norte, la pasaban peor. Los negros eran los primeros en perder el trabajo y los últimos en encontrarlo; tampoco podían integrar los sindicatos ni los gremios. No había nadie quien los proteja ni defienda legalmente. La crisis aceleró el crecimiento de agrupaciones extremistas. La década de 1920 sería testigo del auge del Ku-Klux-Klan, una organización de encapuchados intolerantes, racistas y segregacionistas que con su cotejo de agresiones, linchamientos y ahorcamientos consiguió extender fácilmente su alcance y reclutar miembros por todo el Medio Oeste (Ortiz, 2008).De hecho, Crooks es el único hombre de raza negra californiano en esta novela a quienSteinbeckutilizapara examinar el racismo sostenido por aquellos mismos trabajadores blancos que sufrían la explotación más extrema. Crooks, cuyo apodo se refiere a su espalda torcida, debe dormir solo en el establo y, a diferencia de otros jornaleros, posee una cama de paja, en lugar de una litera. A menudo queda excluido de actividades, como jugar a las cartas o los dados o a las incursiones al burdel;a excepción de la Navidad, cuando el patrón trae una barrica de whisky para todos los muchachos de las barracas. En este sentido, la segregación

\footnotetext{
${ }^{7}$ Como se llamaba a estos migrantes, a veces con connotaciones peyorativas, por su marginalidad social, puesto que junto a otros pobres y desplazados (aunque todos eran americanos y blancos) representaban una amenaza para la comunidad que se deterioraba con la abundancia de mano de obra barata.

${ }^{8}$ Steinbeck, John (2017).De ratones y hombres. Barcelona: Edhasa. Se citará esta traducción al castellano peninsular de Román A. Jiménez a lo largo de todo el trabajo.
} 
por el color de la piel es parte del microcosmos que Steinbeck describe en esta historia. La breve interacción entre Lennie y Crooks revela la complejidad del prejuicio racial en la vida rural del Norte. A pesar de que Crooks es oriundo del lugar, siempre lo hacían sentir como un forastero, incluso en su estado natal. Sin embargo, estamarginación racial alcanza su apogeo en la novela cuando la esposa de Curley ${ }^{9}$, infectada de vanidad porque alguien le había dicho que bien podría ser actriz de cine, pone a Crooks "en su lugar de negro" diciéndole que basta una palabra de ella para hacerlo linchar.

El título de la novela de Steinbeck, poco elocuente pero muy apropiado, nos remite a un poema originalmente escrito en dialecto escocés de Robert Burns (1785) titulado To a Mouse ${ }^{10}$ que contiene líneas como la siguiente: The best-laid schemes of mice and men often go awry. Tanto Burns como Steinbeck igualan a los seres humanosy los animales en un destino adverso: nadie es dueño de su fortuna, pues todos somos víctimas de las circunstancias. Ambos autores supieron condensar la idea de que tanto ratones como hombres son incapaces de escapar a un futuro inmutable. Los planes, los sueños, las esperanzas, los anhelos y las ilusiones largo tiempo albergados se desvanecen ante la imposibilidad de controlar las circunstancias desafortunadas que nos desvían de nuestro cauce. La novela, empezando por el título, no hace sino actualizar el determinismo biológico decimonónico, un paraíso definitivamente perdido (antes de ser encontrado) que se revela en el nombre de uno de los protagonistas ${ }^{11}$.

Of Mice and Men es una parábola conmovedora y sutil sobre dos jornaleros, viajando hacia el Oeste en busca de trabajo, esperanza y dignidad. Lennie Small sufre una discapacidad intelectual $^{12}$, pero su gran fuerza física, su inocencia infantil y su extraña fascinación por acariciar cosas suaves (ratones, cachorros, conejos, cabellos y vestidos) conspiraron contra él. George Milton, un trabajador común de aficiones corrientes essu devoto protector quien, además, se responsabiliza de la vida (y de la muerte) de Lennie. Ambos sueñan con ahorrar lo suficiente como para tener su propia granja con cultivos, animales y mascotas:

\footnotetext{
${ }^{9}$ En la novela no se la conoce con otro nombre.

${ }^{10}$ To a Mouse. On turning her up in her nest with the plought. En http://www.hellesdon.org/documents/To\%20A\%20Mouse.pdf. Consultado el9 de enero de 2020.

${ }^{11}$ George Milton.

${ }^{12}$ En la novela no se habla de esta discapacidad intelectual, sino que se la oculta deliberadamente.
} 
Bueno. Algún día... vamos a reunir dinero y vamos a tener una casita y un par de acres de tierra y una vaca y unos cerdos $y . .$.

— Y viviremos como príncipes — gritó Lennie—. Y tendremos conejos ¡Vamos, George! Cuenta lo que vamos a tener en la huerta y habla de los conejos en las jaulas y de la lluvia en el invierno y la estufa, y háblame de la crema de leche, tan espesa que apenas la podemos cortar. Cuéntamelo todo, George.

— ¿Por qué no lo dices tú? Lo sabes todo.

—No..., dilo tú. No es lo mismo si hablo yo. Vamos..., George ¿Cómo me vas a dejar que cuide los conejos?

-Bueno. Vamos a tener una buena huerta y una conejera y gallina. $Y$ cuando lleguen las lluvias en invierno, no diremos más que "al diablo con el trabajo", y haremos un buen fuego en la estufa y nos sentaremos y oiremos la lluvia cayendo sobre el techo... ¡Tonterías! (Steinbeck, 2017: 11)

La desesperada necesidad de creer en un mundo mejor tiene la cualidad magnética y mágica de un hechizo. Este gran"sueño americano" de todo trabajador rural, la idea de poseer una granja y convertirse en pequeños propietarios independientes, está maldito desde el inicio de la novela (con el incidente en el pueblo de Weed-que se relata dos veces- en el cual Lennie ha sido acusado de intentar violar a una mujer cuando la tocó para sentir la suavidad de su corto y entalladovestido rojo) y se irá obstaculizando hasta llegar a ser imposible (con el incidente final sobre el río Salinas en el cual George le dispara a Lennie por la espalda para evitar el linchamiento).George y Lennie simbolizan una pequeña parte de los millones de trabajadores temporales, quienes nunca tendrán acceso a nada más allá de un burdel, tabaco o un poco de licor.

Ustedes no hacen más que engañarse. No hacen más que hablar y hablar, pero no van a tener nunca esa tierra. Usted va a seguir barriendo aquí hasta que lo saquen en un cajón con los pies por delante. Diablos, he visto ya muchos como ustedes. Lennie, éste, se irá del rancho y volverá al camino dentro de dos, tres semanas. Parece como si todos tuvieran un terreno en la cabeza 
[...] Jesús, muchas veces he visto lo mismo. He visto demasiados hombres con sus tierras en la cabeza. (Steinbeck, 2017: 55)

Sin embargo, y a diferencia del resto de los jornaleros itinerantes, George y Lennie se tienen el uno al otro:

Los hombres, como nosotros, que trabajan en los ranchos, son los tipos más solitarios del mundo. Llegan a un rancho y trabajan hasta que tienen un poco de dinero, y después van a la ciudad y malgastan su dinero, y nos les queda más remedio que ir a molerse los huesos en otro rancho. No tienen nada que esperar del futuro [...] Con nosotros no pasa así. Tenemos un porvenir. Tenemos alguien con quien hablar, alguien que piensa en nosotros. No tenemos que sentarnos en un café malgastando el dinero sólo porque no hay otro lugar donde ir. Si esos otros tipos caen en la cárcel, pueden pudrirse allí porque a nadie le importa. Pero nosotros, no. (Steinbeck, 2017: 11)

El argumento sencillo, la estructura (casi) teatral ${ }^{13}$, relatada con trazos rápidos y sin rodeos (a excepción de algunas descripciones)son suficientes para retratar un mundo estructurado por hombres poco educados, pero emocionalmente ricos.

Soledad, aburrimiento, segregacionismo, indigencia, desamparo, vulnerabilidad de los débiles, deshumanización en el trato, animalización del trabajo manual, inestabilidadlaboral, salarios indignos, abuso de poder, violencia y discriminación. Hombres huraños hacinados en barracascon la redentora compañía de una prostituta ocasional, un trago de alcohol o un partido de naipes.

El final deja al lector con un pequeño estupor, una sutil desazón porque el tiro de George no solo mata a Lennie sino, y sobre todo, a su propio sueño americano. La muerte de los

\footnotetext{
${ }^{13}$ La obra se podría dividir en tres actos de dos escenas cada uno. Cada capítulo (aunque algunas ediciones carecen de numeración) correspondería a una escena. Los sucesos en el rancho ocurren en un período de tres días (de jueves a domingo) en cuatro locaciones fijas y específicas: un bosque, una barraca, la habitación de un peón y el granero, respetando así las tres unidades griegas. La presentación y descripción de los personajes es dialogada (con indicaciones mínimas) y prescinde de la prosa expositiva. Todas estas características la asemejan más a un guion teatral o cinematográfico que a una novela, lo que explica su fácil adaptación a los escenarios de Broadway y a las películas de Hollywood (Bloom, 2006: 14).
} 
ratones que acaricia Lennie es premonitoria del destino de los hombres y nos remite, una y otra vez, al título de la obra.

\section{Conclusión}

Quienes, como Weber y Hobsbawm escriben la historia del siglo XX, consideran que esta centuria fue la de mayor trascendencia histórica,ya que en ella se registró una serie de cambios profundos e irreversibles para la vida humana de todo el planeta.Probablemente, el crack del mercado bursátil neoyorkino y la Gran Depresión tengan un interés histórico más limitado,en comparación con otras catástrofes del siglo $\mathrm{XX}^{14}$. Sin embargo, de no producirse la crisis económica, no hubieran existido el New Deal de F. Roosevelt ni tampoco Of Mice and Men de J. Steinbeck. Esta brevísima obra nos ayuda, a través de la ficción literaria, a comprender mejor las profundas consecuencias que tuvo ese hundimiento económico en el devenir de la historia del pueblo norteamericano. La economía capitalista mundial pareció derrumbarse en el período de entre guerras; pero también en esta época surgieron algunas de las obras más importantes de la literatura estadounidense y del canon occidental. Of Mice and Men es un documento de protesta social que denuncia las condiciones de vida en los ranchos californianos y los efectos devastadores de la mayor y más importante depresión económica de la historia moderna. Puede resultar ofensiva para los moralmente sensibles; sin embargo, John Steinbeck ha tratado los temas con compasión y honestidad.Una narrativa breve de alto impacto que, con crudo realismo, describe la oleada de trabajadores llegados a la California fértil procedentes del medio-oeste espoleados por la sequía, las malas cosechas y la falta de trabajo. La claridad y sencillez de la narrativa de John Steinbeck forman parte de su intención de divulgar los problemas de la clase rural subocupada estadounidense. Una catástrofe financiera que arrasó con los cimientos de la prosperidad de los EE.UU. y con la ilusión de George y Lennie. En términos de Peter Watson (2003: 127): "Se puede considerar a Steinbeck como el cronista por antonomasia del desempleo de los años treinta".

\footnotetext{
${ }^{14}$ Las Guerras Mundiales, el Holocausto, Chernóbil, Hiroshima y Nagasaki, entre otras.
} 
Of Mice and Men ha sido tan criticada como asignada a las aulas: asesinatos, violencia, discapacidad (física y mental), lenguaje obsceno, prostitución, promiscuidad, racismo, sexismo, misoginia, en fin, un catálogo de formas alternativas de vejación. Mantiene el triste mérito de aparecer en la lista de la American Library Association ${ }^{15}$ como uno de los libros más cuestionados y censurados del siglo XX, por ser arriesgado, controvertido y por el empleo de lenguaje vulgar y racista, según algunos críticos. Claramente, no es un elogio al estilo de vida estadounidense, el país de las oportunidades que presume de salir siempre adelante gracias al propio esfuerzo. Pero aquí no hay esfuerzo individual que alcance. Por otro lado es, al mismo tiempo, un canto a la amistad, a la ciega devoción, a la piedad y a la inocencia.

Es, sin duda, un texto obligatorio en la currícula escolar estadounidense, y debería serlo para aquellos interesados en mirar la historia económica mundial desde una perspectiva más humana.

\section{Bibliografía}

Bloom, H. (2006).Bloom's Guides: Of Mice and Men. USA: Chelsea House.

Blumenthal, K. (2013).Six Days in October. The Stock Market Crash of 1929; a Wall Street Journal Book for Children. USA: Simon \& Schuster.

Fraser, S.(2006).Wall Street, a Cultural History. USA: Faber \& Faber.

Hobsbawm, E. (1999).Historia del siglo XX. Buenos Aires: Crítica.

Lamata, F. (1998).Manual de administración y gestión sanitaria. Madrid: Diaz de Santos.

Reis, R. (2008). Great History Disasters: The Dust Bowl. USA: Chelsea House.

Remini, R. (2008). A Short History of the United States. USA: HaperCollins.

Shillinglaw, S. (2006). A Journey into Steinbeck's California. USA: Roaring Forties Press.

Steinbeck, John (1993). Of Mice and Men. England: Penguin.

(2002a). Las uvas de la ira. España: Cátedra.

(2002b). The Harvest Gypsies: On the Road to the Grapes of Wrath.USA: HeydayBooks.

\footnotetext{
${ }^{15}$ Véase Banned \& Challenged Books (1996-2021). "Frequently Challenged Books". Disponible en: http://www.ala.org/advocacy/bbooks/frequentlychallengedbooks. Consultado el 9 de enero de 2020.
} 
(2002c).The Play-Novelette. En America and Americans and Selected Nonfiction. USA: VikingPenguin.

_ (2017). De ratones y hombres (Trad.Román A. Jiménez). Barcelona: Edhasa.

Weber, M. (2001). Historia económica general.México: FCE.

Ortiz,M. (2008). Historia gráfica del siglo XX: Los locos años veinte (1920-1929). Vol.3. España: Labor.

Watson, P. (2003). Historia intelectual del siglo XX. España: Crítica. 